\title{
Mobile Attendance Class Register (MACR): The Effective Way to Take Class Attendance in Urban Schools of Zambia
}

\author{
Kambole M. Bwalya ${ }^{1}$, Phiri Nerbart ${ }^{2}$ \\ Department of Education \\ Information and Communications University \\ P.O Box 30226 \\ Cairo Road, Lusaka, Zambia.
}

\begin{abstract}
The monitoring of student class attendance in Zambian schools is an important process as it is directly linked to the academic performance of the students. Student class attendance registration is currently manually taken by the teachers in schools. This process is not an easy task especially if the class has a big number of students. It consumes too much time and effort for teachers to complete the attendance record and then enter into the official manual attendance and class registers. In this paper, we propose a Mobile Attendance Class Register System (MACR), as a solution for automating the current manual student register system for urban Primary and Secondary schools in Zambia. Further, we design and develop the said Mobile Attendance Class Register (MACR) as an effective way to take class attendance in Urban Schools of Zambia based on Android smart phone devices. Android mobile phones have been proposed to be used by teachers for marking class attendance register due to the popularity of the android operating system. Also, the android platform is an open source platform and can easily be accessed. The methodology of this work involves the design and development of a website and android based Mobile Class Attendance System application to be installed on the teacher's mobile phone where attendance is recorded via the mobile phones. We have also made use of "php", "html", "MySQL" server in this project. The system enables parents to receive notices when their child is present or absent and are able to give feedback. The school Head teacher, Deputy Head teacher and the immediate supervisors of individual teachers have access to the system and can acknowledge having received information and whether it's correct or not.
\end{abstract}

Keywords: Mobile Class Attendance, Mobile Device, Database.

\section{INTRODUCTION}

Zambia has experienced an explosive growth in the telecommunication sector. The use of mobile devices has since become affordable and many Zambians have easy access to handheld devices. The simple handheld devices use the Wi-Fi and can access the internet [1]. The mobile handheld devices are easy to operate by most people despite their training or education background. The proposed system will help teachers manage the student's information. Currently, the Zambian Schools are using the manual registers and teachers do manual work when collecting data, process and storing the same information in the books known as class registers. Teachers call out the individual learners' names one by one then indicate present, late, sick and or absent depending on the status of the child everyday from Monday to Friday. Therefore, in order to reduce the ambiguity involved in these manual tasks, a Mobile Attendance Class Register (MACR) is proposed address the above mentioned problem.

\section{LITERATURE REVIEW}

\section{A. Android Based Class Record System}

This Android-based Class Record System aimed to improve teacher's instruction and classroom management with the use of information and communication technology. It was designed to simplify the process of taking student attendances and handling their academic records. It is a mobile-based application program designed to run on any android mobile phone. A faculty member who wishes to use this application is required to install an android application. The faculty/teacher clicks the Setting button to display the validation interface of the system. It is a user's log-in screen that enables the application to connect to the schools' database server. Concurrently, this also validates if a user is a legitimate faculty member of the said school. Hitting the save button stores the data in the internal database of the mobile phone which will be used later on for the checking of new school calendar and for the updates of the record. [2]

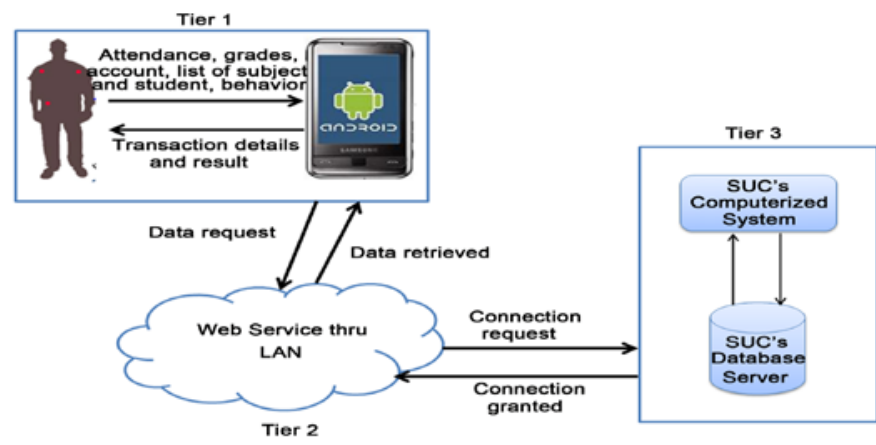

Figure 1. System Architecture of Android Based Class Record System [2] 
B. Mobile Based Attendance Management System

This system uses android studio operating system, PHP MySQL wamp server. It is a web-based system. It has the central administration that controls all the modules in the system. Admin module, registration module and teacher module are the three modules in the system. The administration has all the rights to monitor any new, updated and deleted information. The overall system design diagram is shown in figure 2 below [3].

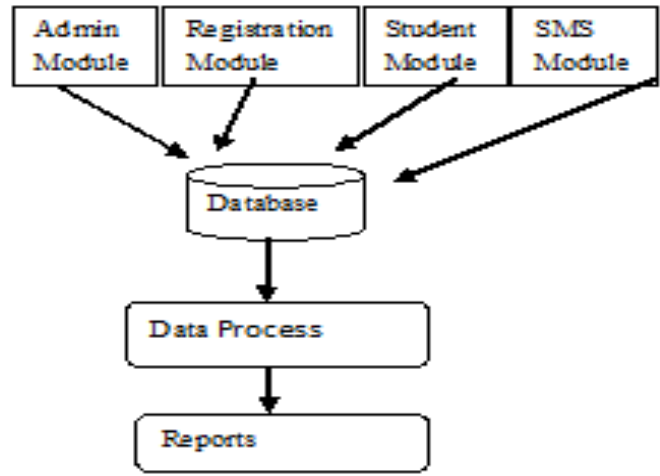

Figure 2. System Design of Mobile Based Attendance Management System [3]

\section{Mobile Application for Student Attendance and Mark Management System}

The mobile application for the student attendance and mark management system was developed and deployed in the cloud server. This application is also installed in the mobile devices of the users such as student, staff and parents, faculty members for accessing the student marks and attendance details. The users are divided into two groups namely student and staff. The student user can be either students or parents. The staff user can be the staff members, faculty member, principal, dean, etc. of the educational institution. The student users can view the attendance and marks that are uploaded in the database or cloud server. The staff users can enter, edit, modify and update the marks and attendance of the student through any mobile device [4]. The system architecture of this project is shown in figure 3.

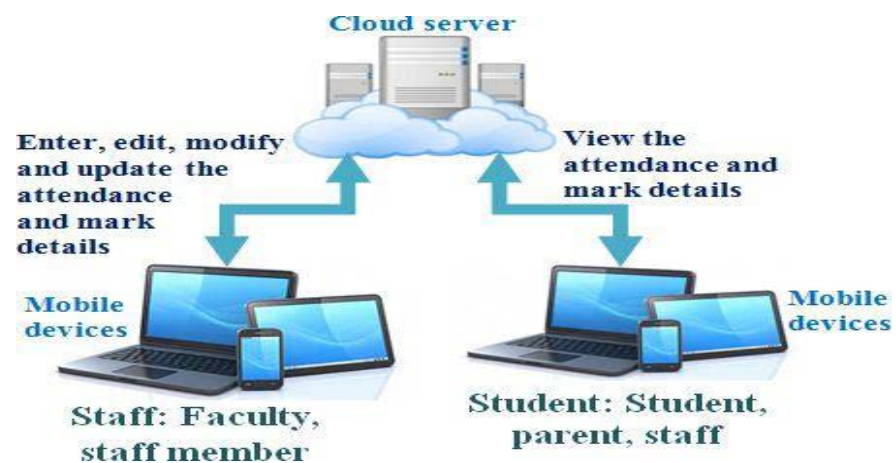

Figure 3. Architecture of Mobile Application for Student Attendance and Mark Management System [4]
III. EXISTING MANUAL SCHOOL REGISTERS

The existing student registers in most Primary and Secondary schools in Zambia at present are manual. Teachers collect data manually and thereafter continue registering learners on a daily basis in a given term. This manual system of registering students involves entering student details such as name, date of birth, grade, date of entry, name of parent/guardian and weekly beginning in the register books. They also manually calculate the numbers of days that each pupil has attended in a week, month and eventually in a term.

These registers consume too much time to generate the desired information and because of this process, teachers end up making mistakes and errors. Figures 4 and 5 below show the manual registers that are currently being used at Chamboli Primary School in Kitwe district of Zambia.

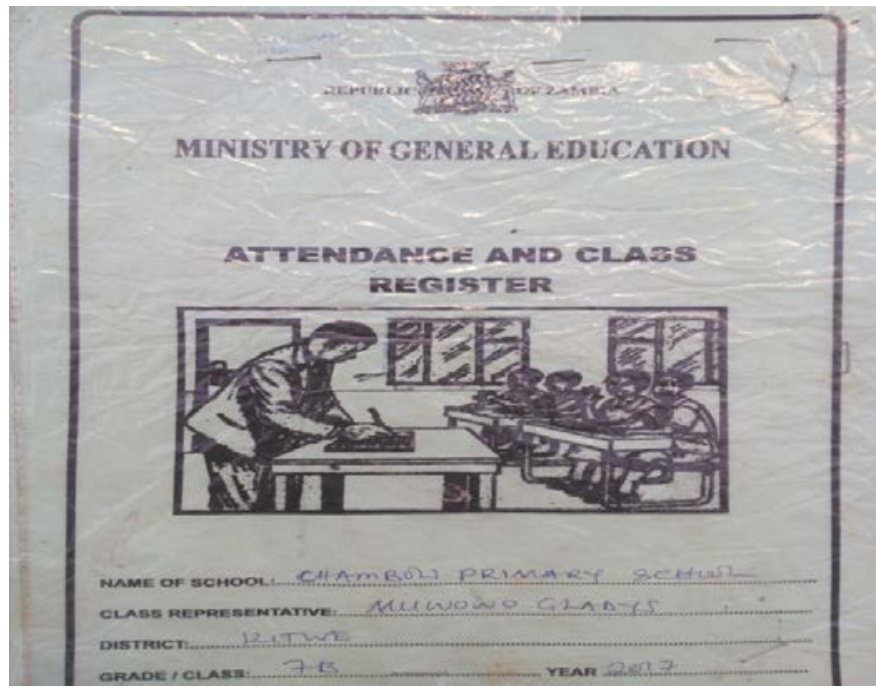

Figure 4. Existing Manual Attendance and Class Registers. Source: Author

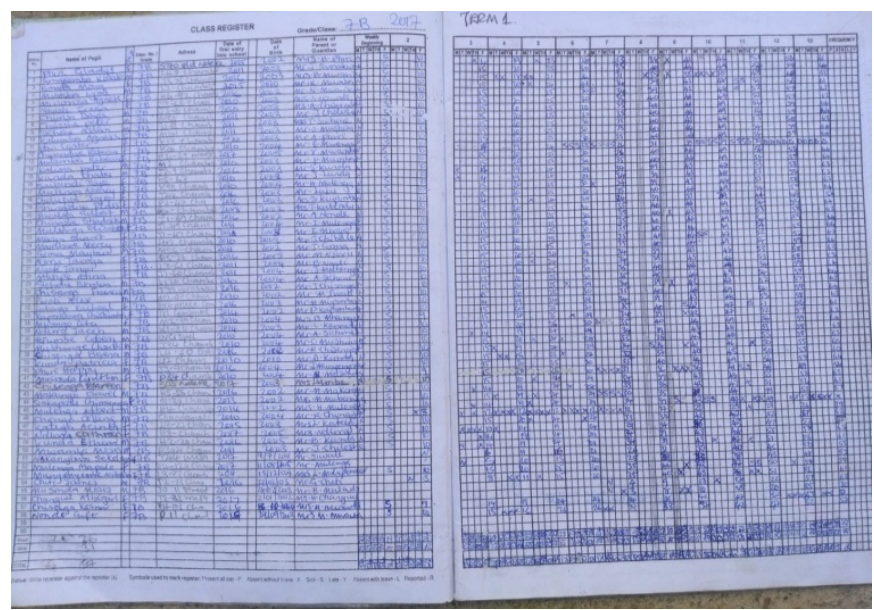

Figure 5 Student Details Manually written in Attendance and Class Registers. Source: Author

\section{PROPOSED SYSTEM DESIGN}

In order to overcome the challenges brought about by the manual register system, where registering of pupils involves the manual entering of their details such as name, date of birth, grade, date of entry, name of parent/guardian and weekly beginning in the register books, We propose a 
Mobile Class Attendance Register (MACR) as an effective way to take class attendance in urban schools of Zambia. The proposed system also uses short message service (sms) to notify parents or guardians when the pupil is absent and parents to give reasons why their child is absent on particular day. The proposed system integrates the applications of the hardware part such as a laptop and an android smart phone while the software includes HTML, SQL, PHP and Android Studio.

The proposed architecture of the system is shown in figure 6 below.

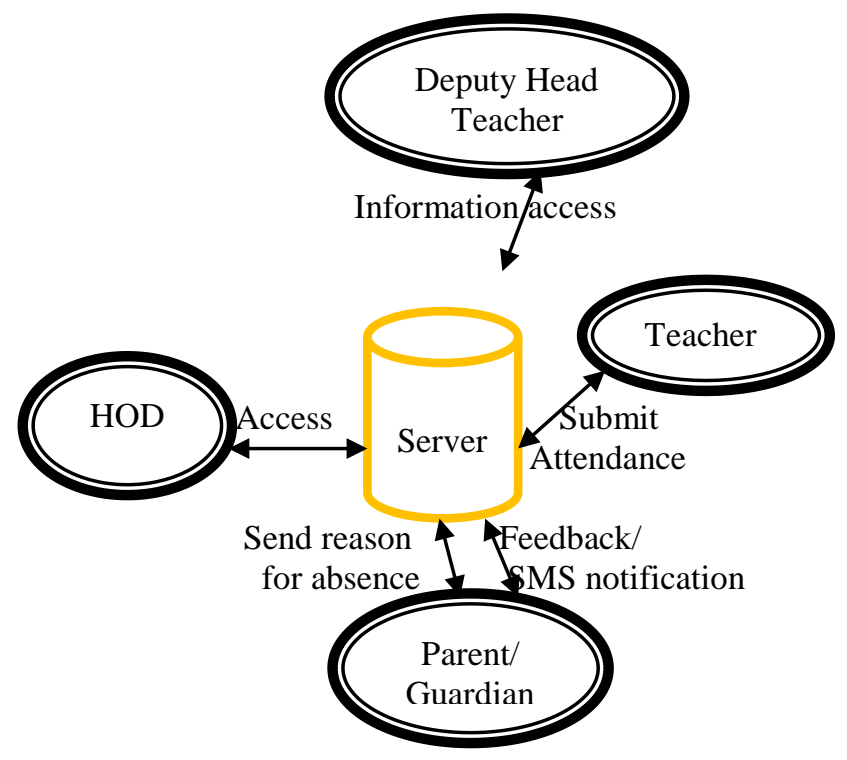

Figure 6: Proposed System Diagram. Source: Author

\section{A. Working Principle}

The system has three main different modules namely admin login module, teacher login module and parent login module. The administrator identified by the school admin especially from the computer department can log into the system using some credentials provided. A computer connected to the internet can allow the administrator to open the website. Once he/or she is logged in, the administrator will be directed to a homepage. He can then access the system and be able to view, add teacher details and view student attendance.

\section{B. Signal Flow Graph}

The working principle explained above for the case of the administrator access to the system, can be summarized by the signal flow graph as shown in figure 7 below.

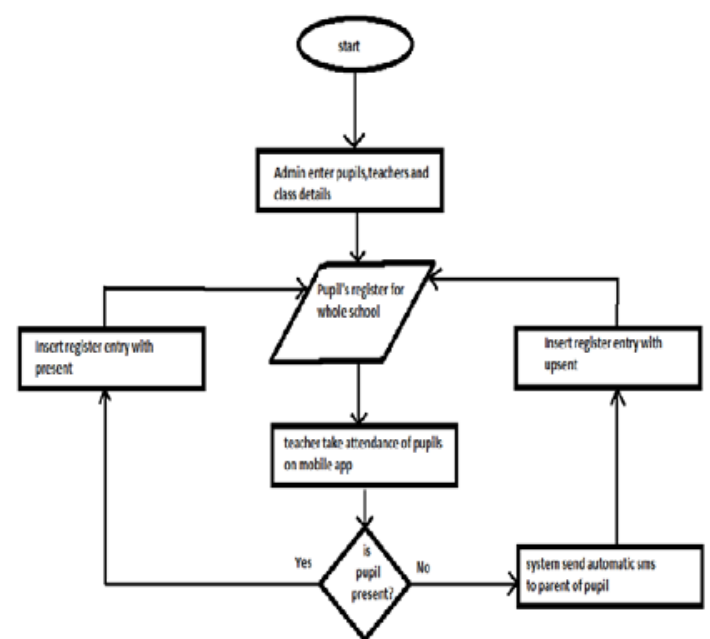

Figure 7 Signal flow graph for Mobile Attendance Class Register System Administrator Login. Source: Author.

\section{Hardware and Software Specifications}

The hardware and software specifications requirements for this project are as listed in table 1.1 and 1.2 below.

Table 1.1: Hardware Specifications

\begin{tabular}{|l|l|}
\hline Computer & Specifications \\
\hline Hard Drive & $500 \mathrm{~GB}$ \\
\hline RAM & $3 \mathrm{~GB}$ \\
\hline Processor & Intel ${ }^{\circledR}$ core ${ }^{\mathrm{TM}}$ i3 \\
\hline Android Smart Phone & Octa-core $1.5 \mathrm{GHz}, 2.0 \mathrm{RAM}$ \\
\hline
\end{tabular}

Table 1.2: Software Specifications

\begin{tabular}{|l|l|}
\hline Operating system & Windows 7 32 bit \\
\hline Xampp & Version 3.2.2 \\
\hline Apache Server & Version 2.4.25 \\
\hline Android Studio & Android 6.0.1 \\
\hline
\end{tabular}

\section{System Testing}

This Mobile Class Attendance Class Register is aimed at simplifying the process of taking class attendance and handling student details such as class teacher name, subjects registered e.t.c. All class teachers are required to install the android application on their mobile phones. System testing involves testing individual components of the system. It includes the forms in each of the modules to make sure that they are working as intended and to make sure that errors do not occur during the usage of the system. At the same time, if errors occur, they need to be fixed immediately and this reduces the number of faults in the system [8] 
Table 1.3: Administrator Login Testing

\begin{tabular}{|c|c|c|c|c|}
\hline NO & $\begin{array}{c}\text { TEST } \\
\text { TEXT }\end{array}$ & $\begin{array}{c}\text { ATTRIBUTE } \\
\text { AND VALUE }\end{array}$ & $\begin{array}{c}\text { EXPECTED } \\
\text { RESULTS }\end{array}$ & $\begin{array}{c}\text { RESULT } \\
\text { OBTAINED }\end{array}$ \\
\hline 1. & $\begin{array}{c}\text { Verify } \\
\text { login } \\
\text { "Login } \\
\text { button" }\end{array}$ & $\begin{array}{c}\text { Username: } \\
\text { superuser } \\
\text { Password: } \\
\text { admin }\end{array}$ & $\begin{array}{c}\text { Successfully } \\
\text { logged in on } \\
\text { (MACR) }\end{array}$ & pass \\
\hline 2. & $\begin{array}{c}\text { User login } \\
\text { with no } \\
\text { value }\end{array}$ & $\begin{array}{c}\text { Username: } \\
\text { NULL } \\
\text { Password: } \\
\text { NULL }\end{array}$ & $\begin{array}{c}\text { Please fill out } \\
\text { this field }\end{array}$ & Pass \\
\hline 3. & $\begin{array}{c}\text { User login } \\
\text { with } \\
\text { incorrect } \\
\text { value }\end{array}$ & $\begin{array}{c}\text { Username: } \\
\text { bwalya } \\
\text { Password: } \\
\text { Kambole }\end{array}$ & $\begin{array}{c}\text { Enter correct } \\
\text { credentials }\end{array}$ & Pass \\
\hline
\end{tabular}

Table 1.4: Parent/Guardian Login Testing

\begin{tabular}{|c|c|c|c|c|}
\hline NO & TEST TEXT & $\begin{array}{c}\text { ATTRIBUTE } \\
\text { AND VALUE }\end{array}$ & $\begin{array}{c}\text { EXPECTED } \\
\text { RESULTS }\end{array}$ & $\begin{array}{c}\text { RESULT } \\
\text { OBTAINED }\end{array}$ \\
\hline 1. & Verify login & $\begin{array}{c}\text { Username: } \\
\text { parent } \\
\text { Password: } \\
8442 \\
\text { button" }\end{array}$ & $\begin{array}{c}\text { Successfully } \\
\text { logged in on } \\
\text { (MACR) }\end{array}$ & Pass \\
\hline 2. & $\begin{array}{c}\text { parent login } \\
\text { with no value }\end{array}$ & $\begin{array}{c}\text { Username: } \\
\text { NULL } \\
\text { Password: } \\
\text { NULL }\end{array}$ & $\begin{array}{c}\text { Please fill out } \\
\text { this field }\end{array}$ & Pass \\
\hline 3. & $\begin{array}{c}\text { parent login } \\
\text { with incorrect } \\
\text { value }\end{array}$ & $\begin{array}{c}\text { Username: } \\
\text { incorrect } \\
\text { Password: } \\
\text { incorrect }\end{array}$ & $\begin{array}{c}\text { Enter correct } \\
\text { credentials }\end{array}$ & Pass \\
\hline
\end{tabular}

Table 1.5: Add Teacher Testing

\begin{tabular}{|c|c|c|c|c|}
\hline NO & TEST TEXT & $\begin{array}{c}\text { ATTRIBUTE } \\
\text { AND VALUE }\end{array}$ & $\begin{array}{c}\text { EXPECTED } \\
\text { RESULTS }\end{array}$ & $\begin{array}{c}\text { RESULT } \\
\text { OBTAINED }\end{array}$ \\
\hline 1. & $\begin{array}{c}\text { "Submitted } \\
\text { button" }\end{array}$ & - & $\begin{array}{c}\text { Teacher } \\
\text { Successfully } \\
\text { submitted }\end{array}$ & Pass \\
\hline
\end{tabular}

Table 1.6: Add Class Testing

\begin{tabular}{|c|c|c|c|c|}
\hline NO & TEST TEXT & $\begin{array}{c}\text { ATTRIBUTE } \\
\text { AND VALUE }\end{array}$ & $\begin{array}{c}\text { EXPECTED } \\
\text { RESULTS }\end{array}$ & $\begin{array}{c}\text { RESULT } \\
\text { OBTAINED }\end{array}$ \\
\hline 1. & $\begin{array}{c}\text { "Submit } \\
\text { button" } \\
\text { To check } \\
\text { whether the } \\
\text { two buttons } \\
\text { are working }\end{array}$ & - & $\begin{array}{c}\text { Successfully } \\
\text { submitted }\end{array}$ & Pass \\
\hline
\end{tabular}

Table 1.7: Add Student Testing

\begin{tabular}{|c|c|c|c|c|}
\hline $\begin{array}{l}\mathrm{N} \\
\mathrm{O}\end{array}$ & $\begin{array}{l}\text { TEST } \\
\text { TEXT }\end{array}$ & $\begin{array}{c}\text { ATTRIBUT } \\
\text { E AND } \\
\text { VALUE }\end{array}$ & $\begin{array}{c}\text { EXPECTE } \\
\text { D } \\
\text { RESULTS }\end{array}$ & $\begin{array}{c}\text { RESULT } \\
\text { OBTAINE } \\
\text { D }\end{array}$ \\
\hline 1. & $\begin{array}{l}\text { Checking } \\
\text { the submit } \\
\text { buttons } \\
\text { "Submitte } \\
\text { d button" }\end{array}$ & 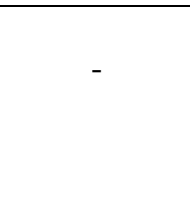 & $\begin{array}{c}\text { student } \\
\text { Successfull } \\
\text { y submitted }\end{array}$ & Pass \\
\hline
\end{tabular}

Table 1.8: View Attendance Report Testing

\begin{tabular}{|c|c|c|c|c|}
\hline $\begin{array}{l}\mathrm{N} \\
\mathrm{O}\end{array}$ & $\begin{array}{l}\text { TEST } \\
\text { TEXT }\end{array}$ & $\begin{array}{l}\text { ATTRIBUTE } \\
\text { AND VALUE }\end{array}$ & $\begin{array}{c}\text { EXPECTED } \\
\text { RESULTS }\end{array}$ & $\begin{array}{c}\text { RESULT } \\
\text { OBTAINED }\end{array}$ \\
\hline 1. & $\begin{array}{l}\text { Check the } \\
\text { "Report per } \\
\text { grade" }\end{array}$ & - & $\begin{array}{c}\text { Displays } \\
\text { entire grade } \\
\text { the } \\
\text { attendance }\end{array}$ & Pass \\
\hline 2. & $\begin{array}{l}\text { Check } \\
\text { "Report per } \\
\text { subject” }\end{array}$ & - & $\begin{array}{l}\text { Displays } \\
\text { subject } \\
\text { attendance } \\
\text { for } \\
\text { secondary } \\
\text { students }\end{array}$ & Pass \\
\hline 3. & $\begin{array}{c}\text { Check } \\
\text { "Report per } \\
\text { pupil"” }\end{array}$ & - & $\begin{array}{l}\text { Displays } \\
\text { attendance } \\
\text { per pupil }\end{array}$ & Pass \\
\hline 4. & Grade & - & $\begin{array}{l}\text { Type the } \\
\text { grade you } \\
\text { need to } \\
\text { check: } \\
\text { i.e.” grade } \\
\text { 4B” }\end{array}$ & Pass \\
\hline
\end{tabular}

Table 1.9: MACR Phone Application for Class Teachers

\begin{tabular}{|c|c|c|c|c|}
\hline NO & TEST TEXT & $\begin{array}{c}\text { ATTRIBUTE } \\
\text { AND VALUE }\end{array}$ & $\begin{array}{c}\text { EXPECTED } \\
\text { RESULTS }\end{array}$ & $\begin{array}{c}\text { RESULT } \\
\text { OBTAINED }\end{array}$ \\
\hline 1. & Verify login & $\begin{array}{c}\text { Username: } \\
\text { enter phone } \\
\text { number: } \\
\text { 0910882255 } \\
\text { Password: } \\
\text { "Login } \\
\text { button" }\end{array}$ & $\begin{array}{c}\text { Successfully } \\
\text { logged in on } \\
\text { (MACR) }\end{array}$ & Pass \\
\hline 2. & $\begin{array}{c}\text { User login } \\
\text { with no } \\
\text { value }\end{array}$ & $\begin{array}{c}\text { Username: } \\
\text { NULL } \\
\text { Password: } \\
\text { NULL }\end{array}$ & $\begin{array}{c}\text { Please enter } \\
\text { your } \\
\text { password }\end{array}$ & Pass \\
\hline 3. & $\begin{array}{c}\text { User login } \\
\text { with } \\
\text { incorrect } \\
\text { value }\end{array}$ & $\begin{array}{c}\text { Username: } \\
\text { bwalya } \\
\text { Password: } \\
\text { Kambole }\end{array}$ & fails to login & Pass \\
\hline
\end{tabular}

Table 2.0: Marking Register Testing

\begin{tabular}{|c|c|c|c|c|}
\hline $\mathrm{NO}$ & TEST TEXT & $\begin{array}{l}\text { ATTRIBUTE } \\
\text { AND VALUE }\end{array}$ & $\begin{array}{c}\text { EXPECTED } \\
\text { RESULTS }\end{array}$ & $\begin{array}{c}\text { RESULT } \\
\text { OBTAINED }\end{array}$ \\
\hline 1. & $\begin{array}{l}\text { Marking the } \\
\text { register }\end{array}$ & 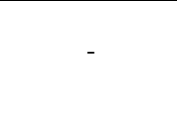 & $\begin{array}{l}\text { Successfully } \\
\text { marked with a } \\
\text { tick on } \\
\text { MACR }\end{array}$ & Pass \\
\hline 2. & $\begin{array}{l}\text { Finish } \\
\text { button }\end{array}$ & - & $\begin{array}{l}\text { Successfully } \\
\text { finished }\end{array}$ & Pass \\
\hline 3. & $\begin{array}{c}\text { Finish } \\
\text { marking } \\
\text { Confirm by } \\
\text { pressing } \\
\text { 'No' } \\
\text { 'Yes 'button }\end{array}$ & - & $\begin{array}{l}\text { Successfully } \\
\text { display the } \\
\text { confirmation } \\
\text { text " total } \\
\text { number of } \\
\text { present is 6" }\end{array}$ & Pass \\
\hline
\end{tabular}

\section{E. Results and Discussion}

This section presents the results obtained after the project design was completed. It shows the various components of the designed Mobile Attendance Class Register (MACR) system. The system itself is available online and designed for access using computers and android mobile devices. Figure 8 below shows the home page of the system when accessed through a computer (or a device that has a larger display screen such as a tablet). 

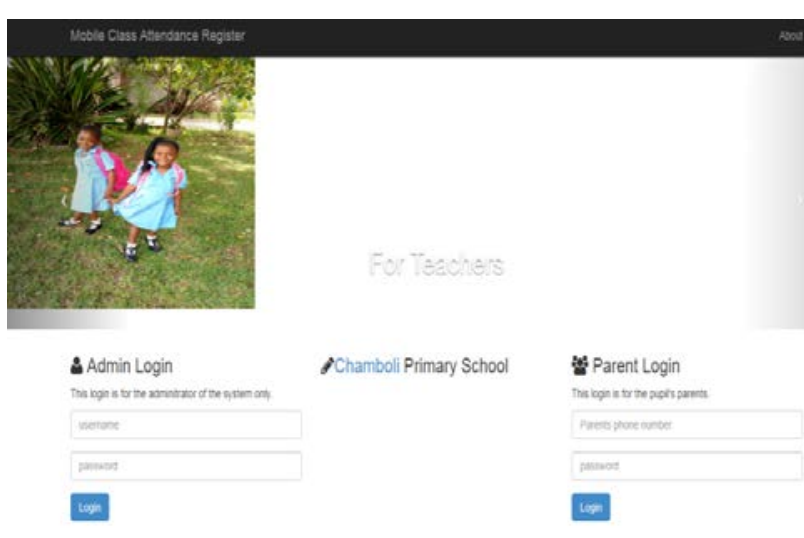

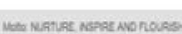

Figure 8 Mobile Attendance Class Register (MACR) System Home Page Source: Author

\section{Administrator Login}

As can be seen from figure 8 above, access to the system is via a username and corresponding password. This is for security purposes and enables access for different user categories such as administrator and parents respectively. When the administrator logs into the system, its display is as shown in figure 9 below.

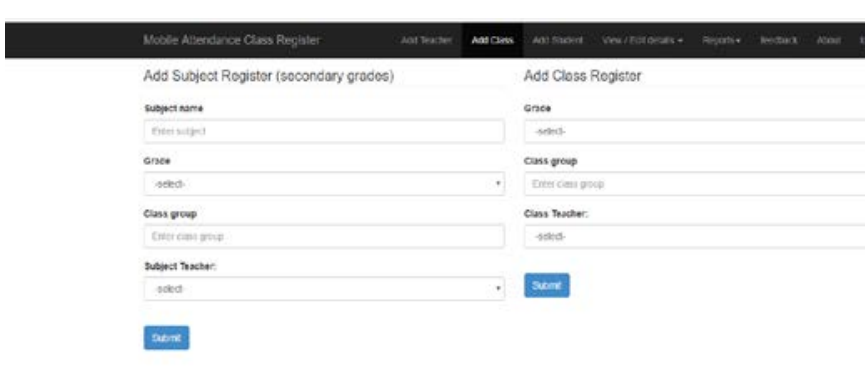

Figure 9 The interface after logging into the system

In the display shown in figure 9 above, the tabs on top show the available choices. The administrator is able to add teachers, add class, view/edit details, generate student attendance reports, view feedback from the parents as well as update the details in the system.

When the administrator clicks on the 'Add Teacher' button, the display is as shown in figure 10 below.

Add teacher

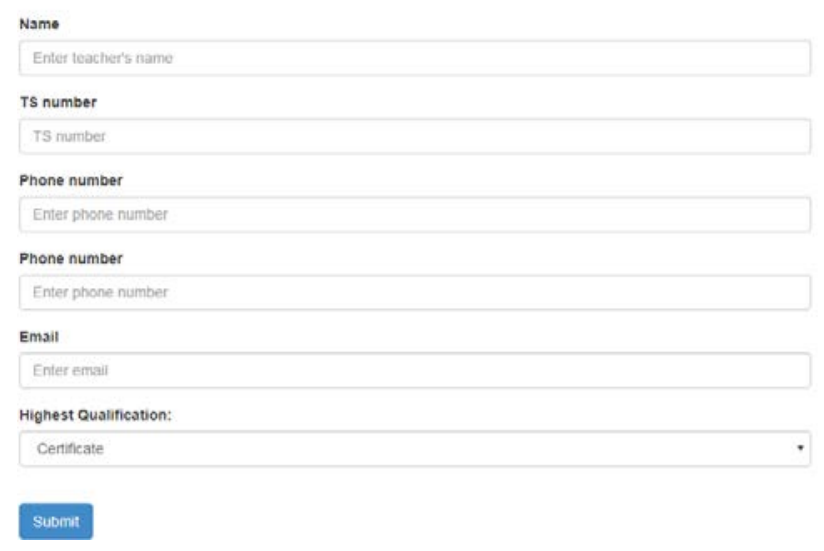

Figure 10. Display after Administrator Clicks Add Teacher Button.
As can be observed from figure 10 above, the administrator can enter teacher details such as name, teaching service (TS) number, mobile phone number, email address and highest qualification held by individual teachers. Once this information is submitted, it is successfully stored in the database.

When the administrator clicks Add Class button, the display is as shown in figure 11 below.

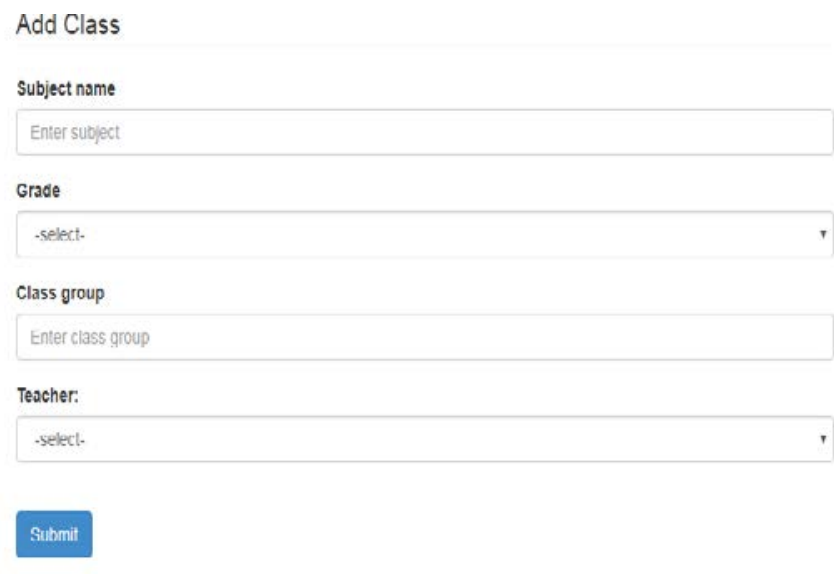

Figure 11 Display after Administrator Click Class Teacher Button

As can be seen from above figure, the administrator can then assign subjects, grade and group to the individual teachers.

\section{Parent Login}

Parents log into the system with their mobile phone numbers as usernames and password generated by the system and given to them by the system administrator. Each parent has a unique username and password. Figure 12 below shows the display after a parent logs into the system.
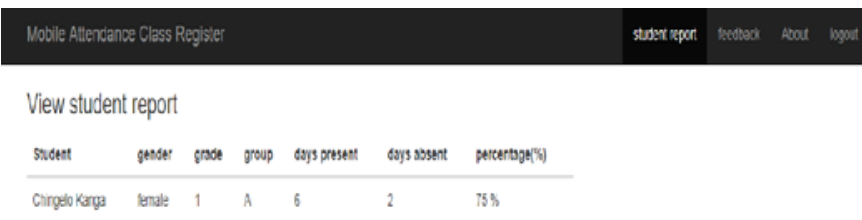

Figure 12 Display after Parent logs into the system

When a parent logs into the system with his/her username and corresponding password, the system automatically directs him/her to his/her child's report because each parent is linked only to their child and can only view their child's report.

The parents are able to view how many days their child has been present in school as well as how many days he/she has been absent. The system also calculates a child's overall class attendance as a percentage. 


\section{Parent feedback}

When a parent clicks on the feedback button, the display is as shown in figure 13 below.

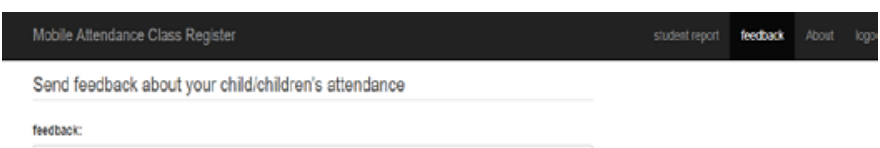

$$
\text { teecossec }
$$

Figure 13 Display after Parent clicks feedback button.

As can be observed from the screen shot above, a parent is able to submit their feedback on their child's attendance. Once the feedback is submitted, it is then stored in the database. The admin can also view this feedback from the parents.

Mobile Attendance Class Register (MACR) Android Phone Application Interface

The main menu for the MACR application to be used by the class teacher or the grade teacher when taking the register is as shown in figure 14 below.

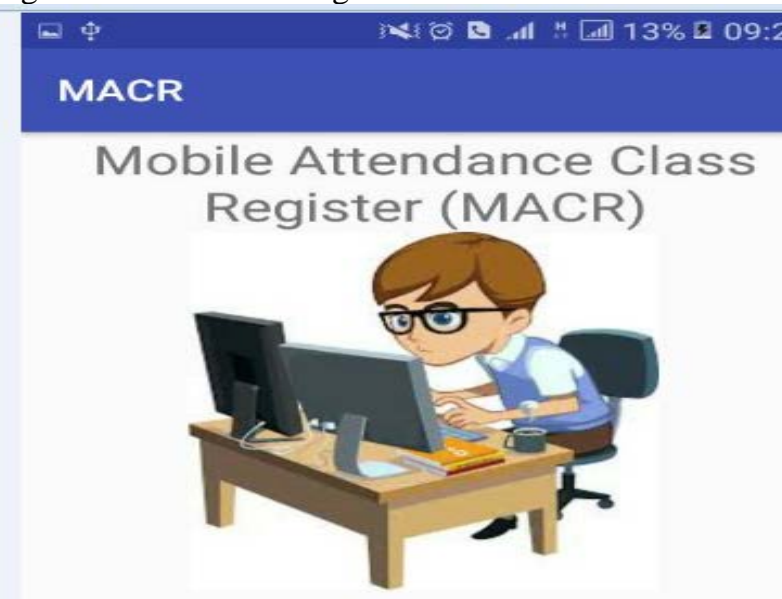

Enter phone number

Enter Password

\section{LOGIN}

Figure 14 MACR Android Phone Application Homepage.

Once a teacher enters his/her username and corresponding password; he/she is directed to his class containing all the students that he/she teaches per grade as shown in figure 15 below.

\begin{tabular}{l|}
\hline MACR \\
12-Jul-2018 \\
Class: 4 C \\
andrew sarafina \\
\hline chola chomba \\
\hline daneil ngandu \\
\hline sapanoi banda \\
\hline betha nyambezi \\
\hline jessy sampa \\
\hline sakina lombe \\
\hline kilvin mwansa \\
\hline lina bwalya \\
\hline mapalo mapalo \\
\hline
\end{tabular}

Figure 15 Display after Teacher logs into the System on an Android Mobile phone

Taking Attendance Class Register

From the display shown in figure 15 above, in order to take the class attendance, the teacher simply ticks by simply clicking on all the students that are present. He/she then clicks finish button and then the system asks the teacher to confirm the class attendance or not as shown in figure 16 .

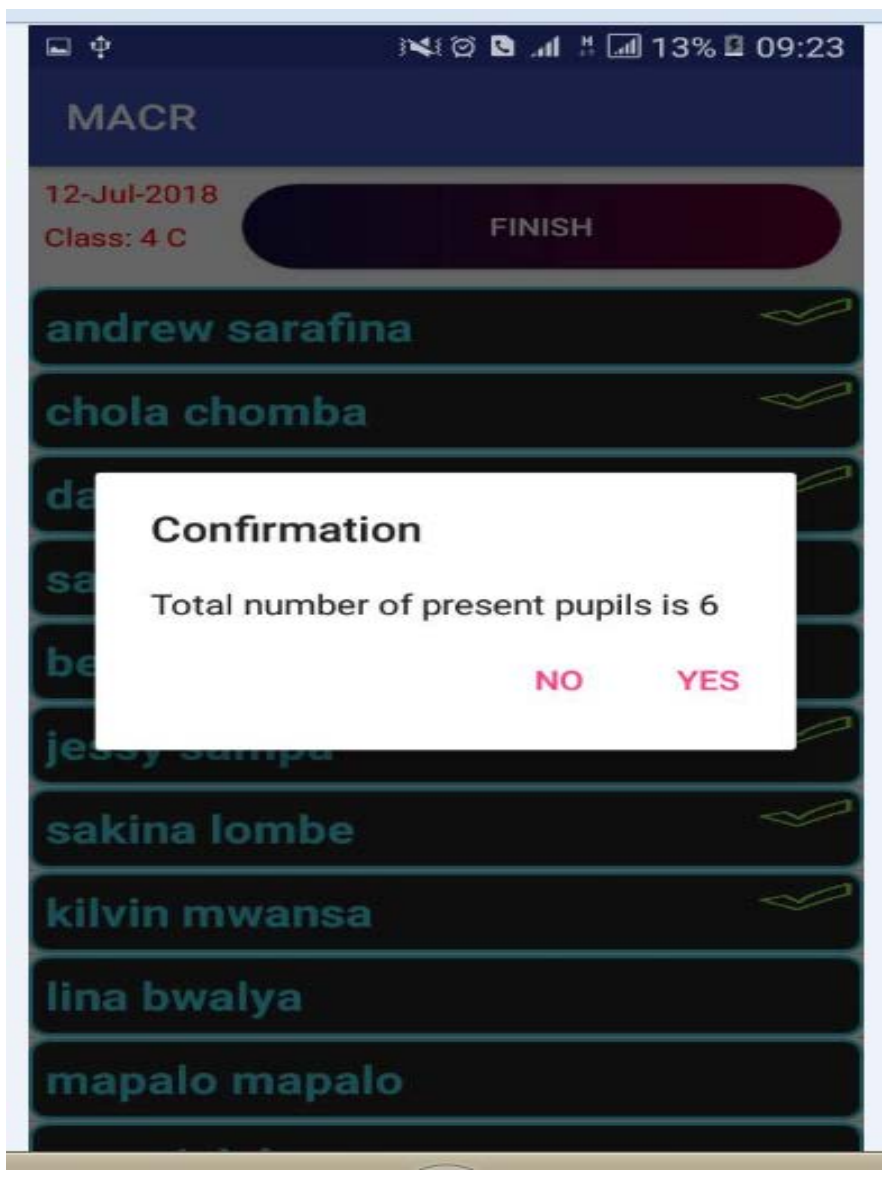

Figure 16 Display after Teacher ticks the Class Attendance 
The class attendance details are successfully updated in the system once the teacher confirms the attendance by clicking the "YES" button. This information can then be accessed by the school administrator.

\section{CONCLUSION AND FUTURE WORK}

In this paper, we have successfully designed a Mobile Attendance Class Register (MACR) for urban Primary and Secondary Schools in Zambia to automate the process of registering students. The system is ready and preliminary tests will be done by teachers at Chamboli Primary School in Kitwe District of Zambia. Any practical issues encountered during the tests will be used to further improve system performance and reliability. The MACR application shown in figure 14 is only developed for Android devices due to the popularity of this operating system. In conclusion, the technology that is presently widely used can be used so that teachers can easily take class attendance and also reduce the falsification of class attendance.

Registration of students' attendance is not an easy task especially if the class has a big number of students. This process consumes too much time and effort for teachers to complete the attendance record and then enter into the official manual attendance and class registers. The proposed system stores student attendance information in a database which provides for flexibility and speed in accessing and updating the data.

In future, in order to avoid a situation where a teacher gives his/her username and password to another teacher to help him/her enter the class attendance when he/she is absent from work and also to avoid marking present for students who are absent from school, we propose analyzing and identifying teacher and student images by installing cameras at the entrances to the classes. We further propose that this work be extended to rural parts of the country as well.

\section{ACKNOWLEDGMENT}

We would like to express our sincere appreciation to all the people who have helped us at various stages in refinements of this project. Special thanks go to Mr. Willie Ngosa and Mr. Kingfrey Chifuka, the head teacher at Chamboli Primary School in Kitwe district of Zambia and many others that have not been mentioned by name.

Above all, we would like to thank the almighty God for the sufficient grace given to us to enable us complete this work.

\section{REFERENCES}

[1] ZICTA ICT Survey report for household -2015 [online] available at: www.zicta.zm/views/publication/2015ICTSURVEYREPORT

[2] Resuello, J.L. (2017) Android-Based Class Record System. Open Access Library Journal, 4: e3461. https://doi.org/10.4236/oalib.1103461

[3] Singh M., Tripathi D. , Pandey A. , Singh R.K, "Mobile based student Attendance management system”, May 2017, Volume 165, No.3. Available on: www.ijcaonline.org/archives/volume165/number3/singh-2017913834.pdf

[4] V. Somasundaram etal "Mobile Based Attendance Management System" Indian Journal of Science and Technology

[5] D.A Singh etal "Mobile Application for Student Attendance and Mark Management System" International Journal of Computational Intelligence Research, ISSN 0973-1873 Volume 13, Number 3 (2017), pp. 425-432

[6] S. Chawhan, Shraddha. (2013). Mobile Phone Based Attendance System. IOSR Journal of Computer Engineering. 10. 48-50. 10.9790/0661-01034850.

[7] Rastogi A., Gupta K., "Student Attendance Through Mobile Devices" May, 2013. available on: www.ethesis.nitriki.in/5195/109CS0146.pdf

[8] Don, W., 1999. Unit Tests, [Online], Available: http://www.extremeprogramming.org/rules/unittests.html.

[9] Singh M., Tripathi D. , Pandey A. , Singh R.K, "Mobile based student Attendance management system”, May 2017, Volume 165, No.3. Available on: www.ijcaonline.org/archives/volume165/number3/singh-2017913834.pdf

[10] w3school, "HTML INTRODUCTION," 9 September 2017. [Online]. Available: https://www.w3schools.com/html/default.asp

[11] w3school, "JAVA SCRIPT HOME," 9 September 2017. [Online]. Available: https://www.w3schools.com/js/default.asp.

[12] "Introduction to SQL," 9 September 2017. [Online]. Available: https://www.w3schools.com/sql/sql_intro.asp.

[13] w3school, "PHP Intro," 9 September 2017. [Online]. Available: https://www.w3schools.com/php/default.asp. 